\title{
The Bacillus subtilis 168 csn gene encodes a chitosanase with similar properties to a Streptomyces enzyme
}

\author{
Luis A. Rivas, Víctor Parro, Mercedes Moreno-Paz and Rafael P. Mellado
}

Centro Nacional de Biotecnología (CSIC), Campus de la Universidad Autónoma, Cantoblanco, 28049 Madrid, Spain

\author{
Author for correspondence: Rafael P. Mellado. Tel: +34 91 5854547. Fax: +34 915854506. \\ e-mail : rpmellado@cnb.uam.es
}

\begin{abstract}
The Bacillus subtilis 168 csn gene encodes a chitosanase. It was found that transcription of the csn gene was temporally regulated and was not subject to metabolic repression. Chitosanase synthesis was abolished in a csn mutant strain. Csn was overproduced in B. subtilis, partially purified and characterized. The deduced amino acid sequence, $K_{\mathrm{m}}$, and optimal $\mathrm{pH}$ and temperature of the $B$. subtilis enzyme were closer to those of a chitosanase from Streptomyces sp. N174 than to those of chitosanases from other Bacillus strains.
\end{abstract}

Keywords: chitosanase, Bacillus subtilis, gene expression, catabolite repression

\section{INTRODUCTION}

Chitosans are a wide range of linear polysaccharides consisting of $1,4-\beta$-linked D-glucosamine residues, partially substituted with $N$-acetyl groups to various degrees of acetylation. In nature, chitosan appears in significant amounts (around $30 \%$ of dry weight) in the cell walls of the Zygomycetes, a group of fungi comprising phytopathogens (Rhizopus) and opportunistic human pathogens (Mucor); chitosan is also present, although in smaller amounts, in the cell wall of other fungi and in some green algae such as Chlorella (Davis \& Eveleigh, 1984). Chitosanases (EC 3.2.1.132) catalyse the hydrolysis of the glycosidic bonds of chitosan and have been used to obtain chitosan oligomers for clinical application as wound-healers, blood anticoagulants and haemostatic materials; chitosan oligomers have also been used as moisturizing agents, food and feed additives, waste-water treatment agents, fertilizers and seed coating fungistatic agents (Sandorf, 1989; Hirano, 1996).

An estimated 1-7\% of heterotrophic soil bacteria synthesize chitosanases (Davis \& Eveleigh, 1984) and chitosanase activities have been reported in a variety of microbial species and plants (rewieved by Somashekar \& Joseph, 1996); genes encoding chitosanases have also been identified in the Chlorella PBCV-1 and CVK2 viruses (Lu et al., 1996; Yamada et al., 1997). Some chitosanases have been characterized and their amino

Abbreviation: LR-PCR, long-range PCR. acid sequences determined, such as the one from Fusarium solani f. sp. phaseoli SUF368 (Shimosaka et al., 1996) and a few others of bacterial origin, including those of Bacillus ehimensis EAG1 (Akiyama et al., 1999), Bacillus circulans MH-K1 (Yabuki et al., 1988), Streptomyces sp. N174 (N174 chitosanase; Boucher et al., 1992), Nocardioides sp. N106 (Masson et al., 1995) and 'Matsuebacter chitosanotabidus' 3001 (Park et al., 1999). The crystal structures of Streptomyces sp. N174 (Marcotte et al., 1996) and B. circulans MH-K1 (Saito et al., 1999) chitosanases are available.

This paper describes the isolation and expression of the csn gene from Bacillus subtilis 168 originally identified in our laboratory (GenBank accession no. X92868; Parro et al., 1997a). The gene was cloned and propagated in $B$. subtilis, and the chitosanase was overproduced, partially purified and biochemically characterized.

\section{METHODS}

Bacterial strains, plasmids and media. B. subtilis 168 (trpC2) cells were cultured in Luria Broth (LB) (Sambrook et al., 1989) or minimal medium, consisting of minimal salts solution (11.4 $\mathrm{mM} \mathrm{K}_{2} \mathrm{SO}_{4}, 62 \mathrm{mM} \mathrm{K}_{2} \mathrm{HPO}_{4}, 44 \mathrm{mM} \mathrm{KH}_{2} \mathrm{PO}_{4}, 3.4 \mathrm{mM}$ sodium citrate, $0.8 \mathrm{mM} \mathrm{MgSO}_{4} \cdot 7 \mathrm{H}_{2} \mathrm{O} ; \mathrm{pH}$ adjusted to 7 with $10 \mathrm{M} \mathrm{NaOH})$, supplemented with $0 \cdot 4 \%(\mathrm{w} / \mathrm{v})$ glucose, $50 \mu \mathrm{g}$ L-tryptophan $\mathrm{ml}^{-1}, 0 \cdot 2 \mathrm{mg}$ L-glutamine $\mathrm{ml}^{-1}, 4 \mu \mathrm{g} \mathrm{FeCl} \mathrm{ml}^{-1}$,

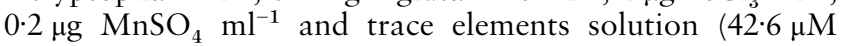
$\mathrm{CaCl}_{2}, 12 \cdot 5 \mu \mathrm{M} \mathrm{ZnCl}, 2 \cdot 5 \mu \mathrm{M} \mathrm{CuCl}_{2}, 2 \cdot 5 \mu \mathrm{M} \mathrm{CoCl}_{2}, 2 \cdot 5 \mu \mathrm{M}$ $\left.\mathrm{Na}_{2} \mathrm{MoO}_{4} \cdot 2 \mathrm{H}_{2} \mathrm{O}\right)$. Kanamycin $\left(10 \mu \mathrm{g} \mathrm{ml} \mathrm{ml}^{-1}\right)$ or chloramphenicol $\left(7 \cdot 5 \mu \mathrm{g} \mathrm{ml}^{-1}\right)$ were added to the media when needed. Escherichia coli MC1061 (hsdR2 mcrB1 araD139 $\Delta(\operatorname{araABC}-l e u) 7679 \Delta$ lacX74 galU galK rpsL thi) was used as 
a host for plasmid propagation. Plasmid pNR2 (Parro \& Mellado, 1993) was used to propagate csn in high copy number. Plasmid pUCAT194 is a pUC19 derivative carrying the EcoRI fragment from pZA327 (a gift from J. C. Alonso) which contains the chloramphenicol resistance gene (cat) and was used as a vector for $c s n$ disruption.

DNA manipulation and PCR amplification. General recombinant DNA manipulation was carried out as described by Sambrook et al. (1989). Restriction endonucleases and DNAmodifying enzymes were from Promega and Boehringer Mannheim. B. subtilis 168 chromosomal DNA was used as a template for PCR amplification and long-range PCR (LRPCR) amplification (Barnes, 1994; Cheng et al., 1994). DNA fragments were purified from low-melting-point agarose gels (LM3; Hispanagar) using Streptomyces coelicolor agarase, which was overproduced and purified in our laboratory (Parro et al., 1997b). Chromosomal DNA was obtained as described by Harwood \& Cutting (1990). PCR and LR-PCR amplifications were carried out in an automated thermocycler (PTC-100; MJ Research). PCR amplification included a denaturation step at $95^{\circ} \mathrm{C}$ for $3 \mathrm{~min}$, followed by 30 cycles of incubation at $95^{\circ} \mathrm{C}$ for $1 \mathrm{~min}, 55^{\circ} \mathrm{C}$ for $1 \mathrm{~min}$ and $72^{\circ} \mathrm{C}$ for $2 \mathrm{~min}$; the reaction was ended by $10 \mathrm{~min}$ incubation at $72^{\circ} \mathrm{C}$. DNA fragments were amplified by using chromosomal DNA $(500 \mathrm{ng})$ from B. subtilis 168 with $1 \mathrm{U}$ EcoTaq polymerase (Ecogen) in the presence of $2 \mathrm{mM} \mathrm{MgCl}_{2}$ and $40 \mathrm{pmol}$ of each primer in a final reaction volume of $100 \mu \mathrm{l}$. To obtain DNA fragments longer than $2 \mathrm{~kb}$, LR-PCR amplification was carried out using the GeneAmpXL kit (Perkin Elmer) and following the manufacturer's instructions. The reaction included a denaturation step at $94^{\circ} \mathrm{C}$ for $5 \mathrm{~min}$, followed by 15 cycles of incubation at $94^{\circ} \mathrm{C}$ for $30 \mathrm{~s}$ and $66^{\circ} \mathrm{C}$ for $10 \mathrm{~min}$, and 11 cycles of incubation at $94{ }^{\circ} \mathrm{C}$ for $30 \mathrm{~s}$ and $66^{\circ} \mathrm{C}$ for $10 \mathrm{~min}$ with an increment of $15 \mathrm{~s}$ per cycle; the amplification was ended by $10 \mathrm{~min}$ incubation at $72{ }^{\circ} \mathrm{C}$. DNA fragments were amplified from B. subtilis 168 chromosomal DNA (500 ng) with 2.0 U Tth DNA Polymerase (Promega) containing $1 \mathrm{mM}$ $\mathrm{Mg}\left(\mathrm{CH}_{3} \mathrm{COO}\right)$, and 40 pmol of each primer in a final reaction volume of $100 \mu \mathrm{l}$. For automatic DNA sequencing, a 373 DNA sequencer from Applied Biosystems and an Edit-View 1.0 DNA sequencer viewer (Applied Biosystems) were used.

Transcriptional analysis and RNA manipulations. Aliquots from the different cultures were lysed (Mellado et al., 1981) and total RNA was extracted as described by Kedzierski \& Porter (1991). High-resolution S1 nuclease protection experiments were as described by Barthelemy et al. (1986), Sambrook et al. (1989) and Parro et al. (1998) using $50 \mu \mathrm{g}$ total RNA. The DNA molecular size ladders were chemically derived (Maxam \& Gilbert, 1980) from the same DNA fragment used as a probe in the experiments. Total RNA was transferred to nylon membranes (Hybond $\mathrm{N}+$; Amersham) and used for Northern analysis as described by Sambrook et al. (1989). Nylon membranes were incubated overnight at $65^{\circ} \mathrm{C}$ in $0.5 \mathrm{M}$ sodium phosphate $\mathrm{pH} 7 \cdot 2,10 \mathrm{mM}$ EDTA, $7 \%$ (w/v) SDS. A PCR internal fragment of the csn gene was amplified from genomic DNA with the oligonucleotides csn2 (5'-GGCGAGGCTATACATGCGGACGGG-3') and csn1 (5'-GGCATTATCCGATCGTTTCATGG-3') as primers. The amplified DNA fragment $(5 \mathrm{ng})$ was used as template to extend $10 \mathrm{pmol}$ primer csn 1 with 5 U sequencing grade Taq DNA polymerase ( $f m o l$ DNA Cycle Sequencing System; Promega) in the presence of $1 \times f m o l$ DNA Sequencing Buffer (Promega). The labelled DNA was used as a probe for Northern analysis.

Pulse-chase and Western blot experiments. One millilitre aliquots from different phases of cell cultures growing in defined medium were labelled with $100 \mu \mathrm{Ci}(3.7 \mathrm{MBq})\left[{ }^{35} \mathrm{~S}\right]$ methionine (Redivue Pro-mix L- $\left.{ }^{35} \mathrm{~S}\right]$ in vitro cell labelling mix; Amersham) in a 0.5 min pulse, following a procedure described previously (Parro \& Mellado, 1994). A 1000-fold molar excess of non-radioactive methionine and cysteine were then added and the incubation continued; $100 \mu \mathrm{l}$ aliquots were removed from the labelled cultures at $0,0 \cdot 5,1,2,5$ and $10 \mathrm{~min}$ after the pulse and the extracellular and intracellular labelled proteins were subjected to immunoprecipitation and analysis by SDS-PAGE (Laemmli, 1970). Proteins were immunoprecipitated as described previously (Parro \& Mellado, 1994) with polyclonal antibodies raised against mature Csn extracted from acrylamide gels (Dunbar \& Schwoebel, 1990). Samples treated with non-immune serum were always run in parallel as a negative control. Pulse-chase labelling experiments were repeated at least twice. Gels were exposed to Molecular Dynamics Storage Phospho Screens. Screens were scanned with a Molecular Imager FX (Bio-Rad) and relative amounts of radioactivity were determined with Quantity One version 4 software (Bio-Rad). ${ }^{14} \mathrm{C}$-methylated molecular mass reference markers were obtained from Amersham.

For Western blot analysis, intracellular and extracellular proteins were fractionated by SDS-PAGE (Laemmli, 1970) and transferred to Immobilon PVDF membranes (Millipore) as described by Timmons \& Dunbar (1990). Half of the transferred material was stained with $1 \%(\mathrm{w} / \mathrm{v})$ Coomassie brilliant blue R-250 in $50 \%$ (v/v) methanol, $20 \%$ (v/v) acetic acid for $15 \mathrm{~min}$. The other half of the transferred material was incubated with antibodies raised against mature Csn and peptides reacting with the antibodies were revealed by further incubation with $0 \cdot 1 \mu \mathrm{Ci}(3.7 \mathrm{kBq}) \mathrm{ml}^{-1}{ }^{125} \mathrm{I}$-labelled protein $\mathrm{A}$ from Staphyloccocus aureus (Amersham), as described by Timmons \& Dunbar (1990). Membranes were exposed to Agfa Curix RP2 film at $-70^{\circ} \mathrm{C}$. Protein concentration in the different samples was determined as described by Bradford (1976), using standard I bovine gamma globulin (Bio-Rad).

Chitosanase assay. Chitosanase activity was assayed as described by Boucher et al. (1992) using the neocuproine reagent (Dygert et al., 1965) for reducing sugar determination and $0.2 \%(\mathrm{w} / \mathrm{v})$ chitosan flakes (practical grade; Sigma) dissolved in $50 \mathrm{mM}$ sodium acetate buffer $\mathrm{pH} 5.7$ as substrate. Activity was measured after $15 \mathrm{~min}$ incubation at $37^{\circ} \mathrm{C}$. One unit $(\mathrm{U})$ of enzyme is defined as the amount of enzyme that liberated $1 \mu \mathrm{mol}$ D-glucosamine equivalents $\mathrm{min}^{-1}$ under the assay conditions. For chitosanase substrate specificity studies, the substrates were prepared as $2 \mathrm{mg} \mathrm{ml}^{-1}$ solutions or suspensions in $50 \mathrm{mM}$ sodium acetate buffer $\mathrm{pH} 5.5$ and assayed as described above.

Chitosanase purification and analysis. Total protein from $100 \mathrm{ml}$ culture medium of B. subtilis 168(pQC10) in LB was precipitated at $80 \%$ saturation of ammonium sulfate at $4{ }^{\circ} \mathrm{C}$. The precipitate was collected by centrifugation at $12000 \mathrm{~g}$ for $20 \mathrm{~min}$, dissolved in $50 \mathrm{mM}$ Tris/maleate buffer $\mathrm{pH} 7 \cdot 3$ (buffer A) and applied to a $45 \times 1 \mathrm{~cm}$ Sephadex G-100 column (Pharmacia) previously equilibrated with the same buffer. The flow rate of the column was $15 \mathrm{ml} \mathrm{h}^{-1}$. Fractions showing chitosanase activity were pooled $(17.5 \mathrm{ml})$ and applied to an SP-Fast Flow Sepharose $6 \times 2.5 \mathrm{~cm}$ column (Pharmacia) previously equilibrated with the same buffer. The flow rate of the column was $15 \mathrm{ml} \mathrm{h}^{-1}$. Unbound protein was washed from the column with buffer A containing $75 \mathrm{mM} \mathrm{NaCl}$. Elution of chitosanase was carried out at the same flow rate in a step-wise manner with $30 \mathrm{ml}$ buffer A containing 100, 150, 200, 250 and $300 \mathrm{mM} \mathrm{NaCl}$. All purification steps were carried out at $4{ }^{\circ} \mathrm{C}$. Fractions showing chitosanase activity were pooled and the 
purified enzyme was stored at $-20{ }^{\circ} \mathrm{C}$ in $50 \%(\mathrm{v} / \mathrm{v})$ glycerol. The enzyme remained active without loss of activity for approximately 6 months. The $\mathrm{N}$-terminal amino acid sequence of the purified mature chitosanase was determined by Edman degradation in a Procise 494 protein sequencer (Applied Biosystems).

Chitosanase sequences were retrieved from the NCBI GenBank database. The B. circulans MH-K1 chitosanase sequence was the version determined by Saito et al. (1999). Protein sequence comparison and analysis were carried out using the CLUSTAL $\mathrm{W}$ multiple sequence alignment program from the UWGCG package (version 1.7; Thompson et al., 1994). Sequence alignments were adjusted manually taking into account the structural relationships of chitosanases revealed by Saito et al. (1999). Phylogenetic analysis of the aligned sequences was performed using the maximum-parsimony analysis of the Phylogeny Analysis Using Parsimony (PAUP) program version 4.0 (Swofford, 1988) from the UWGCG package.

\section{RESULTS AND DISCUSSION}

\section{The csn gene encodes a chitosanase}

The csn DNA sequence was determined previously (Parro et al., 1997a) and was predicted to encode a chitosanase whose coding sequence is preceded by a putative RBS with a high degree of identity to the consensus RBS of $B$. subtilis. The putative pre-Csn is a 277 amino acid protein with a molecular mass of $31.5 \mathrm{kDa}$. The N-terminal sequence analysis predicted a cleavage site between Ala-35 and Ala-36. The putative Csn signal peptide length (35 aa), hydrophobicity $(0 \cdot 7$; Kyte \& Doolittle; 1982) and number of positive charges (4) are closer to those of the streptomycetes group (mean peptide length, $35 \cdot 5 \pm 7 \cdot 9$; mean hydrophobicity, $0.56 \pm 0.6$, mean number of positive charges, $3.9 \pm 2 \cdot 4$; Edman et al., 1999) than to those of Bacillus (mean peptide length, $28 \cdot 2 \pm 5 \cdot 6$; mean hydrophobicity, $0 \cdot 93 \pm 0 \cdot 4$, mean number of positive charges, $2 \cdot 0 \pm 0 \cdot 9$; Edman et al., 1999). The estimated molecular mass for the 242 amino acid mature Csn was $27 \cdot 4 \mathrm{kDa}$. The deduced amino acid sequence showed significant homology with chitosanases present in the GenBank database (Fig. 1), being closer to those from actinomycetes (Streptomyces sp. N174, 39\% identity and 51\% similarity; Nocardioides sp. N106, 37\% identity and 49\% similarity) (Fig. 1a) than to those from Bacillus (B. ehimensis, $21 \%$ identity and $28 \%$ similarity; $B$. circulans MH-K1 20\% identity and 27\% similarity) (Saito et al., 1999; Fig. 1b). In the B. subtilis mature chitosanase, residues Glu-19 and Asp-35, equivalent to the Glu-22 and Asp-40 suggested to be essential for catalytic activity in N174 chitosanase (Boucher et al., 1995), are conserved and equivalent residues are also present in other chitosanases (Fig. 1). The disulfide bridge between Cys-50 and Cys-124 present in the $B$. circulans MH-K1 (Saito et al., 1999) and B. ehimensis enzymes is not conserved in the Streptomyces sp. N174 and B. subtilis chitosanases. The parsimony analysis of the primary structure of the Streptomyces sp. N174, Nocardioides sp. N106, B. ehimensis, B. circulans MH-
$\mathrm{K} 1$ and B. subtilis 168 mature chitosanases produced a phylogenetic tree where the $B$. subtilis enzyme appeared closer to those of actinomycetes (Fig. 1c).

\section{Transcriptional and translational analysis of the csn gene}

To assess if csn expression was subject to catabolite repression, B. subtilis 168 was grown in LB or minimal medium with different carbon sources: 0.4 or $1 \%$ glucose, $1 \%$ glycerol or $1 \%(\mathrm{w} / \mathrm{v})$ mannitol. Aliquots of the different cultures were lysed and total RNA was extracted at mid-exponential, transition-to-stationary and stationary phases of growth as indicated in the Methods section. A $930 \mathrm{nt}$ monocistronic transcript was detected by Northern blot analysis in all cases, transcription reaching its maximum at the transition-tostationary phase (Fig. 2a), indicating that $c s n$ was temporally regulated and was not subject to catabolite repression. No catabolite repression was expected since no CRE elements (Miwa et al., 2000) were present in the csn regulatory region (Parro et al., 1997a). Csn activity was detected in the supernatant of all cultures (not shown), clearly indicating that no post-transcriptional catabolite repression existed. D-Glucosamine has been reported to induce chitosanase production in Streptomyces (Boucher et al., 1992; Price \& Storck, 1975), but when $1 \%(\mathrm{w} / \mathrm{v})$ D-glucosamine was used as carbon source it did not induce $c s n$ transcription in B. subtilis 168 (Fig. 2a).

Chitosan is not a good carbon source because it precipitates above $\mathrm{pH}$ 6.5. Nevertheless, Northern blot analyses were performed to detect chitosan induction of csn transcription in B. subtilis 168 (pNR2) cultures growing in minimal medium in the presence of $0.4 \%$ glucose as carbon source that was either substituted or supplemented by $0.4 \%$ chitosan in the middle of the exponential phase. Bacterial growth and the csn transcription pattern were unaffected in the latter case (chitosan being ignored as carbon source by the bacteria in the presence of glucose), whereas when glucose was substituted by chitosan the bacterial growth became almost synchronized, with a considerably longer doubling time, resulting in only two generations more, and the csn transcription level diminished as the culture approached stationary phase (results not shown). $B$. subtilis 168 (pNR2) was able to grow in minimal medium containing chitosan as the sole carbon source, but with eight-fold longer doubling time and a much lower cellular mass at stationary phase compared to cultures grown in the presence of glucose (results not shown).

The $c s n$ transcription initiation site was determined by high-resolution S1 nuclease protection experiments, using total RNA from $B$. subtilis 168 growing in minimal medium supplemented with $0.4 \%$ glucose. A $1355 \mathrm{bp}$ PCR fragment containing part of the $\operatorname{csn}$ sequence was amplified by PCR from the B. subtilis genome using oligonucleotides 366I (5'-GACATGTACTTGTTCGGGATGGC- $3^{\prime}$ ), derived from the $y \mathrm{raK}$ gene immediately preceding $c s n$ in the chromosome, and 406I (5'-CAAA- 
(a) Str

NoC

Bsu

Str

NoC

Bsu

Str

NoC

Bsu

Str

NoC

Bsu

Str

Noc

Bsu
1 AGAGLDDPHKKE IAMELVSSA * ${ }^{2}$ SSLDWKAQYKYIEDIGD $\stackrel{*}{ }$ RGYTGGI IGFCSGTGDMLE

1 AAVGLDDPHKKDIAMQLVSSAENSSLDWKSQYKYIEDIKDGRGYTAGI IGFCSGTGDMLD

1 --AGLNKDQKRR-AEQLTS IFENGTTE--IQYGYVERLDDGRGYTCGRAGFTTATGDALE 00 - 0 O

61 LVQHYTDLEPGNILAKYLPALKKVNGSASH--SGLGTPFTKDWATAAKDTVFQQAQNDER 61 LVADYTDLKPGNILAKYLPALRKVNGTESH--AGLASAFEKDWATAAKDSVFQQAQNDER 57 VVEVYTKAVPNNKLKKYLPELRRLAKEESDDTSNL-KGFASAWKSLANDKEFRAAQDKVN

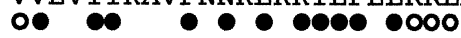

119 DRVYFDPAVSQAKADGLR-ALGQFAYYDAIVMHGPGNDPTSFGGIRKTAMKKA-RTPAQG

119 DRSYFNPAVNQAKA-SLR-ALGQFAYYDAIVMHGPGDSSDSFGGIRKAAMKKA-KTPAQG

115 DHLYYQPAMKRSDNAGLKTALARAVMYDTVIQHGDGDDPDSFYALIKRTNKKAGGSPKDG

177 GDETTYLNAFLDARKAAMLTEAAHD--D-TS----RVDTEQRVFLKAGNLDLNPPLKWKT

176 RDEATYLKAFLAARKTVMLKEEAHS--D-TS----RVDTEQTVFLNAKNFDLNPPLKWKV

175 IDEKKWLNKFLDVRYDDLMNPANHDTRDEWRESVARVDVLRSI-AKENNYNLNGP IHVRS

$230--Y G D P Y V I N S$

229 --YGDSYAINS

234 NEYG-NFVIK-

(b) Beh

$\mathrm{BCi}$

Bsu

Beh

BCi

Bsu

Beh

$\mathrm{BCi}$

Bsu

Beh

$\mathrm{BCi}$

Bsu

Beh

BCi

$\mathrm{Bsu}$
1 ASPDENFSPETLQFLRDRTGLDGEQWNNI-MKLINKPËQDDLNWIKYYGYCEDINDERGY 1 ASPDDNFSPETLQFLRNNTGLDGEQWNNI-MKLINKPEQDDLNWIKYYGYCEDIEDERGY

1

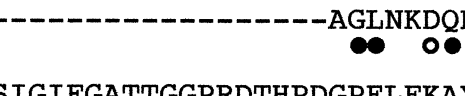

60

SIGIFGA

60 TIGLFGATTGGSRDTHPDGPDLFKAYDAAKGASNPSAD--GALKRLGINGKMKGSILEIK

40 TCGRAGFTTA---T-GDALEVVEVYTKAV-PNNKLKKYLPELRR--LAKEESDDTSNL-

118 DSEKVFCGKIKKLQNDPAWRKAMWETFYNVYIRYSVEQARQRGFTSALTIGSFVDTALNQ

118 DSEKVFCGKIKKLQNDAAWRKAMWETFYNVYIRYSVEQARQRGFTSAVTIGSFVDTALNQ

91 --KGFASAWKSLANDKEFRAAQDKVNDHLYYQPAMKRSDNAGLKTALARAVMYDTVIQH

178 GATGDSNTLQGL----LARSGSST----NEKTFLKKFHAKRTLVVDTNEYNQPPNGKN--

178 GATGGSDTLQGL----LARSGSSS----NEKTFMKNFHAKRTLVVDTNKYNKPPNGKN--

148 GDGDDPDSFYALIKRTNKKAGGSPKDGIDEKKWLNKFLDVRYDDLMNPANHDTRDEWRES - O O

228 --RVK-QWDTLLDMGKMNLKNVDAEIAQVTNWE---

228 --RVK-QWDTLVDMGKMNLKNVDSEIAQVTDWEMK-

208 VARVDVLRSI-AKENNYNLNGP IHVRSNEYGNFVIK
60

60

56

118

118

114

176

175

174

229

228

233

238

237

242

59

59

39

117

117

90

177

177

147

227

227

207

257

259

242 (c)

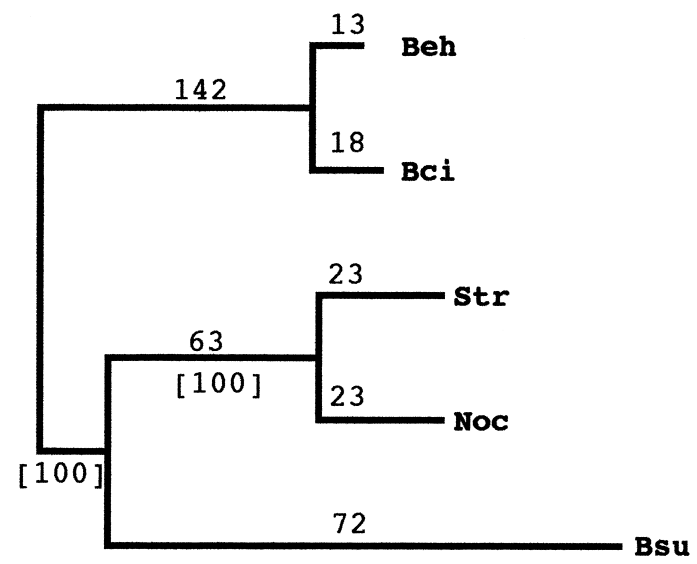

Fig. 1. (a, b) Amino acid sequence comparison of mature chitosanases from (a) B. subtilis 168 (Bsu), Streptomyces sp. N174 (Str) and Nocardioides sp. N106 (Noc); and (b) B. subtilis 168 (Bsu), B. circulans MH-K1 (Bci) and B. ehimensis (Beh). To take into account the structural relationships of chitosanases revealed by Saito et al. (1999), manual alignment was needed. Accepted conservative replacements for the manual alignments were $\mathrm{I}, \mathrm{L}, \mathrm{V}$ and $\mathrm{M} ; \mathrm{D}$ and $\mathrm{E} ; \mathrm{A}$ and $\mathrm{G} ; \mathrm{R}$ and $\mathrm{K} ; \mathrm{S}$ and $\mathrm{T} ; \mathrm{F}$ and $\mathrm{Y}$. Asterisks indicate the conserved Glu and Asp residues equivalent to Glu-22 and Asp-40 from Streptomyces sp. N174 suggested to be essential for the chitosanase activity (Boucher et al., 1995). Identical and similar residues in all sequences are indicated by black and white circles, respectively. (c) Phylogenetic tree of the five chitosanases. Bootstrap replicate values derived from 1000 replications are indicated in square brackets. The relative numbers of substitutions per 100 residues are also indicated. 
(a)

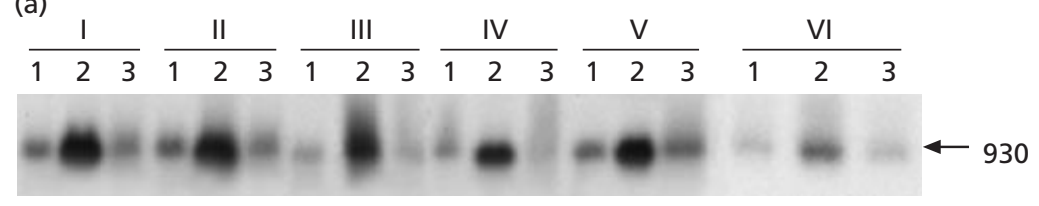

(b)

(c)

(d)

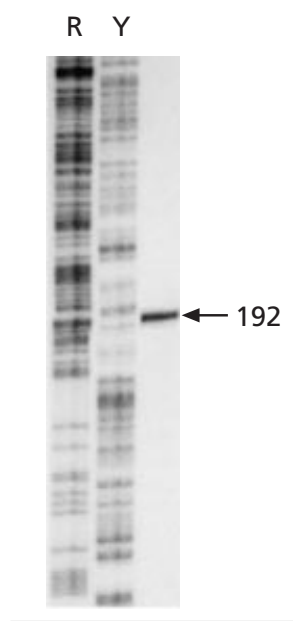

R $\mathrm{Y}$

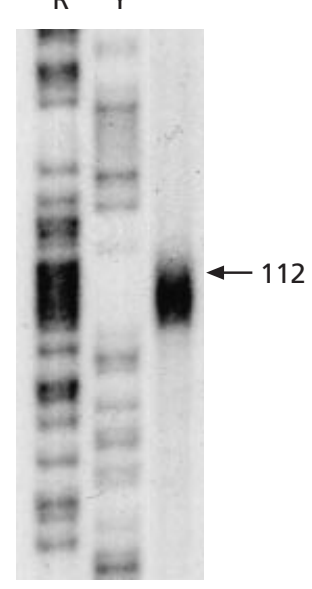

$\Delta G^{0}=-50 \cdot 2 \mathrm{~kJ} \mathrm{~mol}^{-1}$

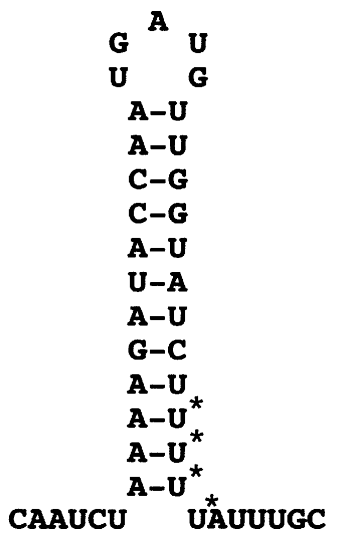

Fig. 2. Transcriptional analysis of the csn gene. (a) Northern blot analysis. Total RNA was extracted at mid-exponential (lane 1), transition-to-stationary (lane 2) and stationary (lane 3 ) phases of $B$. subtilis cell cultures growing in LB (lanes $\mathrm{VI}$ ), or minimal medium supplemented with $0.4 \%$ glucose (lanes I), 1\% glucose (lanes II), 1\% glycerol (lanes III), 1\% mannitol (lanes IV) or 1\% Dglucosamine (lanes $\mathrm{V}$ ). The transcript size (nt) is indicated. (b, c) Transcription initiation (b) and termination (c) sites for csn were determined by $\mathrm{S} 1$ nuclease mapping using $50 \mu \mathrm{g}$ total RNA from $B$. subtilis cultures extracted at transition-to-stationary phase. The size of the protected fragments (nt) is indicated. Lanes $R$ and $Y$ contain the purine and pyrimidine sequence ladders, respectively, resulting from chemical degradation of the radioactively labelled probes run in parallel. (d) The stem-loop structure for the csn terminator. Asterisks indicate the nucleotides where transcription terminates.
GATACTTGTCAGCTGTTCCG-3') and digested with HindIII. A 355 bp fragment thought to contain the csn promoter region was radioactively labelled at its unique $5^{\prime}$ blunt end and used as a probe. A $192 \mathrm{nt}$ protected fragment was detected corresponding to a transcript starting at 33 bp upstream of the csn translation start codon (Fig. 2b). The deduced -35 and -10 regions of the $c s n$ promoter are separated by $17 \mathrm{bp}$ and showed homology to those of the consensus B. subtilis $\sigma^{A}$ promoters (Parro et al., 1997a)

The transcription termination site of the chitosanase gene was also determined by S1 nuclease mapping. A 384 bp DNA fragment was amplified by PCR from the $B$. subtilis genome using oligonucleotides csnt $\left(5^{\prime}\right.$ GAACAACTATAATCTAAACGGACC-3'), derived from the $c s n$ coding sequence, and 145d (5'-GACGGAACAGTTTATACGCATGG-3'), derived from the yraM gene immediately after csn in the chromosome, and digested with Hinfl. The resulting 359 bp fragment was radioactively labelled at its unique $\operatorname{HinfI} 3^{\prime}$ end and used as a probe. A 109-112 nt protected fragment was detected (Fig. 2c), locating the transcription termination site 65-68 nt downstream of the csn translation stop codon; the presence of more than one protected band could be due to the $\mathrm{S} 1$ nuclease nibbling effect previously described (Christie \& Calendar, 1983; Mellado et al., 1986). The stem-loop structure predicted around the transcription termination site is depicted in Fig. 2(d).

To determine the secretion pattern of the chitosanase precursor, total intracellular polypeptides from midexponential, transition-to-stationary and stationary phases of growth from $B$. subtilis 168 cultures grown in minimal medium in the presence of $0.4 \%$ glucose were pulse-labelled with $\left[{ }^{35} \mathrm{~S}\right]$ methionine and chased with a 1000-fold molar excess of non-radioactive methionine and cysteine as described in Methods. The labelled proteins were incubated with antibody raised against the extracellular chitosanase and immunoprecipitated polypeptides analysed by SDS-PAGE. Chitosanase was only detected during the transition-to-stationary phase of growth (Fig. 3a), coinciding with csn transcription being more abundant (Fig. 2a). Pre-Csn was rapidly processed and secreted; within 2 min after the pulselabelled pre-Csn was chased extracellular mature enzyme was detected (Fig. 3a). The relative amounts of precursor and mature forms were determined by densitometer scanning of the autoradiographs. The $15 \%$ of mature chitosanase that remained cell-associated after the 0.5 min pulse illustrates that the passage through the cell wall of $B$. subtilis is an active step during secretion as identified by Leloup et al. (1997) and Bolhuis et al. (1999).

\section{Construction of csn mutant and Csn overproducer strains}

To disrupt $c s n$, a 280 bp DNA fragment from the central part of the $c s n$ coding sequence was amplified by PCR from the B. subtilis 168 chromosome using the csn 2 and csn1 oligonucleotides as primers. The PCR product was purified and inserted into the unique, previously made blunt XbaI site of pUCAT194 to generate plasmid pUCSN1. After propagation in E. coli MC1061, pUCSN1 was used to transform B. subtilis 168. A transformant, BSCAT40, was selected with a single copy of pUCSN1 inserted into $c s n$ through a single crossover event as confirmed by LR-PCR analysis using as primers oligonucleotides $366 \mathrm{I}$ and $145 \mathrm{~d}$, derived from the cor- 


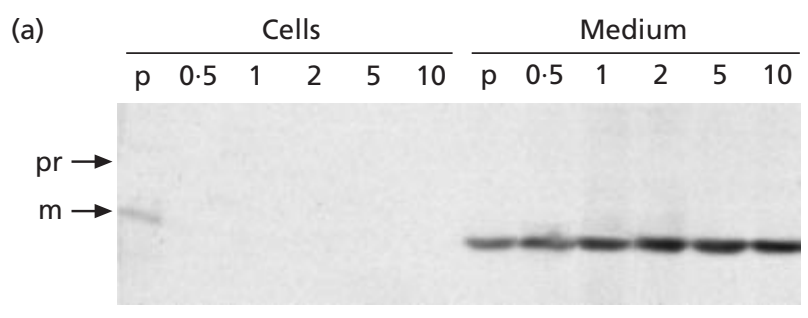

(b)
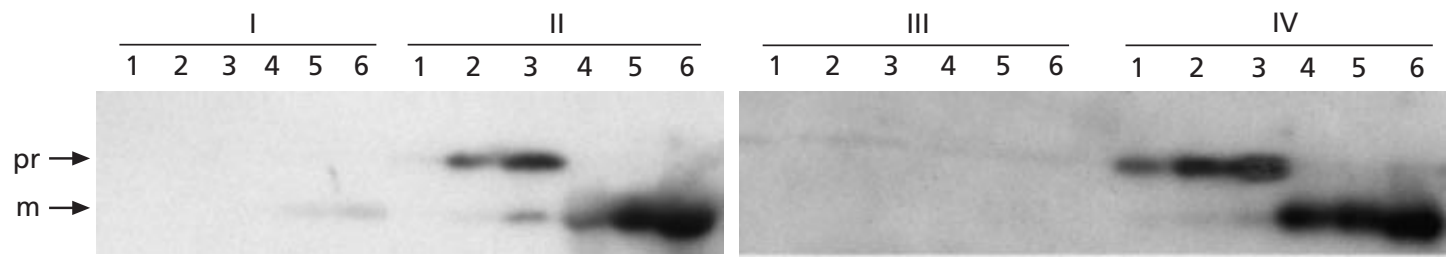

Fig. 3. Chitosanase synthesis. (a) B. subtilis cultures grown in minimal medium supplemented with $0.4 \%$ glucose were pulse-labelled for $0.5 \mathrm{~min}(\mathrm{p})$ and chased for $0.5,1,2,5$ or $10 \mathrm{~min}$ as indicated. Total intracellular ('Cells') and extracellular ('Medium') proteins were subjected to immunoprecipitation using antibodies raised against $B$. subtilis mature Csn, and analysed by $12.5 \%$ SDS-PAGE. (b) Western blot analysis of intracellular (lanes 1-3) and extracellular (lanes 4-6) chitosanase present in B. subtilis 168(pNR2) (lanes I), B. subtilis 168(pQC10) (lanes II), BSCAT40 (lanes III) and BSCAT40(pQC10) (lanes IV) cell cultures grown in minimal medium supplemented with $0.4 \%$ glucose at exponential (lanes 1 and 4), transition-to-stationary (lanes 2 and 5) and stationary (lanes 3 and 6) phases of growth. pr, pre-Csn; m, mature Csn.

responding DNA sequences of the $c s n$ flanking genes, yraK and yraM, respectively (not shown). Western blot analysis of chitosanase production in $B$. subtilis BSCAT40, showed the complete absence of chitosanase (Fig. 3b).

A 2881 bp DNA fragment comprising $c s n$ and flanking regions was amplified by LR-PCR from the B. subtilis 168 chromosome using primers 366I and yraMR $\left(5^{\prime}\right.$ GCCTACTGGAAATAGTTCGGAG-3'), derived from the $y \mathrm{raM}$ gene. The amplified DNA fragment was purified and digested with DraI to obtain a $1634 \mathrm{bp}$ DNA fragment comprising the csn coding region plus the $625 \mathrm{bp}$ preceding it and the $179 \mathrm{bp}$ located behind it in the B. subtilis chromosome. The purified DraI fragment was inserted into pNR2 through its unique SmaI site to generate the high-copy-number plasmid pQC10 that carried csn in the same relative orientation as the cat gene, as confirmed by DNA sequencing. $B$. subtilis 168 (pQC10) produced chitosanase in considerably larger amounts than B. subtilis 168 , as determined by Western blot assays (Fig. 3b), and propagation of pQC10 in the csn mutant B. subtilis BSCAT40 restored its ability to produce the enzyme at equivalent levels (Fig. 3b). B. subtilis 168 (pQC10) was able to grow in minimal medium containing chitosan as the sole carbon source, whereas B. subtilis BSCAT40 did not (results not shown), as expected according to their relative levels of chitosanase production.

\section{Purification and characterization of chitosanase}

Mature chitosanase was purified from stationary-phase supernatants of B. subtilis 168 (pQC10) cultures grown in LB. In that phase of growth, B. subtilis 168(pQC10)

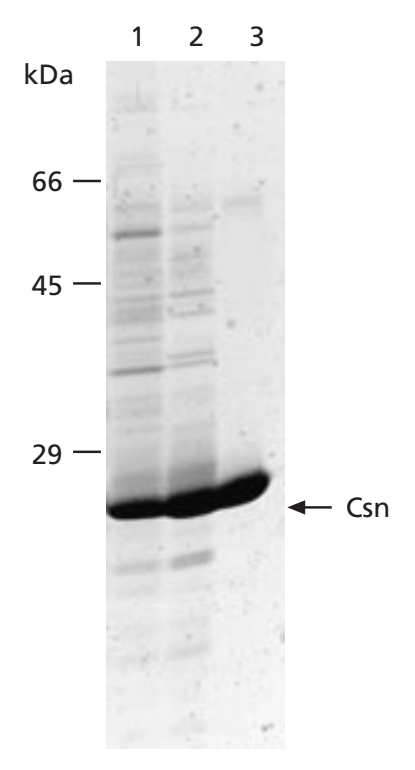

Fig. 4. Chitosanase purification. Coomasie-blue-stained $12 \cdot 5 \%$ SDS-PAGE of total extracellular protein recovered after ammonium sulfate precipitation (lane 1), gel filtration through a G-100 Sephadex column (lane 2) and ion exchange by passage through a SP-Fast Flow Sepharose column (lane 3). A $50 \mu \mathrm{g}$ sample of protein was loaded in each lane.

accumulates aproximately 60-fold more chitosanase activity than B. subtilis 168 (pNR2) in the same culture conditions (results not shown). Mature Csn was purified as described in Methods. The purified enzyme, eluting from the SP-Fast Flow Sepharose column at $250 \mathrm{mM}$ $\mathrm{NaCl}$, was protease-free and almost $95 \%$ pure, as 
determined by SDS-PAGE (Fig. 4). N-terminal sequencing of the purified protein confirmed the predicted length (35 aa) of the leader peptide (not shown). The relative degree of purification of the B. subtilis Csn [specific activity $56.9 \mathrm{U}(\mathrm{mg} \text { protein })^{-1}$, yield $33 \%$, and purification factor 1.83] was comparable to that of the N174 chitosanase, which was purified following a very similar procedure (Boucher et al., 1992).

The optimal $\mathrm{pH}(5 \cdot 7)$ and temperature $\left(60^{\circ} \mathrm{C}\right)$ of the purified Csn resembled those of other characterized chitosanases (Somashekar \& Joseph, 1996) and they are close to those of the N174 chitosanase (pH 5.5 and $65^{\circ} \mathrm{C}$; Boucher et al., 1992). Thermal stability of the enzyme was determined by preincubation at various temperatures (from 37 to $60{ }^{\circ} \mathrm{C}$ ) in the absence of substrate for different periods of time $(0-60 \mathrm{~min})$ in $50 \mathrm{mM}$ acetate buffer $\mathrm{pH} 5.7$ and measurement of the residual activity. The enzyme was stable at $37^{\circ} \mathrm{C}$ for 10 min but the stability rapidly decreased above $50{ }^{\circ} \mathrm{C}$, and after $15 \mathrm{~min}$ at $60^{\circ} \mathrm{C}$ activity dropped by almost $15 \%$. As suggested earlier for other chitosanases (Pelletier \& Sygush, 1990), the apparent discrepancy between the optimum temperature and the lability of chitosanase at $60^{\circ} \mathrm{C}$ may reflect that the optimum temperature is related to the chemical reaction catalysed, whereas thermal stability refers to the lability of the protein structure. Enzyme activity was not affected by $\mathrm{Ca}^{2+}$ and $\mathrm{Mg}^{2+}$, but it was almost completely inhibited by $\mathrm{Fe}^{3+}$ and $\mathrm{Cu}^{2+}$ and inhibited by about $50 \%$ by $\mathrm{Co}^{2+}$, as determined when the different ions were added as $1 \mathrm{mM}$ chloride salts to the reaction. Most of the chitosanases described are inhibited by heavy metal ions and part of the inhibition may be attributable to the chitosan having a strong tendency to form stable complexes with these ions (Yabuki et al., 1988).

Purified B. subtilis chitosanase can hydrolyse glycolchitosan at a similar rate $(23 \%$ relative to $100 \%$ activity on solubilized Sigma chitosan) to that of the N174 chitosanase $(35 \%$ of the maximal rate; Boucher et al., 1992). Although it has been reported that chitosanases from several sources (reviewed by Somashekar \& Joseph, 1996) hydrolyse CM-cellulose and/or chitin to a different extent, Csn cannot do this, as also reported for chitosanases of Streptomyces sp. N174 (Boucher et al., 1992), Nocardioides sp. N106 (Boucher et al., 1992), B. circulans MH-K1 (Yabuki et al., 1988) and B. ehimensis (Akiyama et al., 1999). Chitosan concentrations higher than $1 \mathrm{mg} \mathrm{ml}^{-1}$ inhibited Csn, as also happens with N174 chitosanase (Boucher et al., 1992). The apparent $K_{\mathrm{m}}$ for the B. subtilis 168 chitosanase, determined from a double reciprocal plot (not shown), was $0 \cdot 110 \mathrm{mg} \mathrm{ml}^{-1}$ and its $V_{\max }$ was $66 \cdot 3 \mathrm{U} \mathrm{mg}^{-1}$. These parameter values are similar to those of the N174 enzyme $\left(K_{\mathrm{m}} 0 \cdot 088 \mathrm{mg}\right.$ $\mathrm{ml}^{-1}, V_{\max } 96.5 \mathrm{U} \mathrm{mg}^{-1}$; Boucher et al., 1992) but differ from those of $B$. circulans MH-K1 $\left(K_{\mathrm{m}} 0.63 \mathrm{mg} \mathrm{ml}^{-1}\right.$; Yabuki et al., 1988) and B. megaterium $\left(K_{\mathrm{m}} 0.82 \mathrm{mg}\right.$ $\mathrm{ml}^{-1}$; Pelletier \& Sygush, 1990).

From the results obtained it can be concluded that the csn gene of B. subtilis 168 encodes a chitosanase whose amino acid composition and functional characteristics are close to those of the Gram-positive bacterium Streptomyces sp. N174, despite the phylogenetic distance of their respective genera.

\section{ACKNOWLEDGEMENTS}

This research was supported by grant BIO2-CT95-0278 from the European Union.

\section{REFERENCES}

Akiyama, K., Fujita, T., Kuroshima, K., Sakane, T., Yokota, A. \& Takata, R. (1999). Purification and gene cloning of a chitosanase from Bacillus ehimensis EAG1. J Biosci Bioeng 87, 383-385.

Barnes, W. M. (1994). PCR amplification of up to $35-\mathrm{kb}$ DNA with high fidelity and high yield from lambda bacteriophage templates. Proc Natl Acad Sci US A 91, 2216-2220.

Barthelemy, I., Salas, M. \& Mellado, R. P. (1986). In vivo transcription of bacteriophage $\phi 29$ DNA : transcription initiation sites. J Virol 60, 874-879.

Bolhuis, A., Tjalsma, H., Smith, H. E., de Jong, A., Meima, R., Venema, G., Bron, S. \& van Dijl, J. M. (1999). Evaluation of bottlenecks in the late stages of protein secretion in Bacillus subtilis. Appl Environ Microbiol 65, 2934-2941.

Boucher, I., Dupuy, A., Vidal, P., Neugebauer, W. A. \& Brzezinski, R. (1992). Purification and characterization of a chitosanase from Streptomyces N174. Appl Microbiol Biotechnol 38, 188-193.

Boucher, I., Fukamizo, T., Honda, Y., Willick, G. E., Neugebauer, W. A. \& Brzezinski, R. (1995). Site-directed mutagenesis of evolutionary conserved carboxylic amino acids in the chitosanase from Streptomyces sp. N174 reveals two residues essential for catalysis. J Biol Chem 270, 31077-31082.

Bradford, M. M. (1976). A rapid and sensitive method for the quantitation of microgram quantities of protein utilizing the principle of protein-dye binding. Anal Biochem 72, 248-254.

Cheng, S., Higuchi, R. \& Stoneking, M. (1994). Complete mitochondrial genome amplification. Nature Genet 7, 350-351.

Christie, G. E. \& Calendar, R. (1983). Bacteriophage P2 late promoters. Transcription initiation sites form two late mRNAs. J Mol Biol 167, 773-790.

Davis, B. \& Eveleigh, D. E. (1984). Chitosanases: occurrence, production and immobilization. In Chitin, Chitosan and Related Enzymes, pp. 161-179. Edited by J. P. Zikakis. New York: Academic Press.

Dunbar, B. S. \& Schwoebel, E. D. (1990). Preparation of polyclonal antibodies. Methods Enzymol 182, 663-670.

Dygert, S., Li, L. H, Florida, D. \& Thoma, J. A. (1965). Determination of reducing sugar with improved precision. Anal Biochem 13, 367-374.

Edman, M., Jarhede, T., Sjöström, M. \& Wieslander, A. (1999). Different sequence patterns in signal peptides from Mycoplasmas, other Gram-positive bacteria and Escherichia coli: a multivariate data analysis. Proteins 35, 195-205.

Harwood, C. R. \& Cutting, S. M. (1990). Molecular Biological Methods for Bacillus. Chichester: Wiley.

Hirano, S. (1996). Chitin biotechnology applications. Biotechnol Annu Rev 2, 237-258.

Kedziersdi, W. \& Porter, J. C. (1991). A novel non-enzymatic procedure for removing DNA template from RNA transcription mixtures. Biotechniques 10, 210-214. 
Kyte, J. \& Doolittle, R. F. (1982). A simple method for displaying the hydropathic character of a protein. J Mol Biol 157, 105-132.

Laemmli, U. K. (1970). Cleavage of structural proteins during the assembly of the head of bacteriophage T4. Nature 227, 680-685.

Leloup, L., Haddaoui, E. A., Chambert, R. \& Petit-Glatron, M. F. (1997). Characterization of the rate-limiting step of the secretion of Bacillus subtilis $\alpha$-amylase overproduced during the exponential phase of growth. Microbiology 143, 3295-3303.

Lu, Z., Li, Y., Que, Q., Kutish, G. F., Rock, D. L. \& Von Etten, J. L. (1996). Analysis of $94 \mathrm{~kb}$ of the chlorella virus PBCV-1 330-kb genome: map positions 88 to 182. Virology 216, 102-123.

Marcotte, E. M., Monzingo, A. F., Ernst, S. R., Brzezinski, R. \& Robertus, J. D. (1996). X-ray structure of an anti-fungal chitosanse from Streptomyces N174. Nature Struct Biol 3, 155-162.

Masson, J. Y., Boucher, I., Neugebauer, W. A., Ramotar, D. \& Brzezinski, R. (1995). A new chitosanase gene from a Nocardioides sp. is a third member of glycosyl hydrolase family 46. Microbiology 141, 2629-2635.

Maxam, A. M. \& Gilbert, W. (1980). Sequencing end-labeled DNAs with base-specific chemical cleavages. Methods Enzymol 65, 499-560.

Mellado, R. P., Delius, H., Klein, B. \& Murray, K. (1981). Transcription of sea urchin histone genes in Escherichia coli. Nucleic Acids Res 9, 3889-3906.

Mellado, R. P, Barthelemy, I. \& Salas, M. (1986). In vivo transcription of bacteriophage $\phi 29$ DNA early and late promoter sequences. J Mol Biol 191, 191-197.

Miwa, Y., Nakata, A., Ogiwara, A., Yamamoto, M. \& Fujita, Y. (2000). Evaluation and characterization of catabolite-responsive elements (cre) of Bacillus subtilis. Nucleic Acids Res 28, 1206-1210.

Park, J. K., Shimono, K., Ochiai, N., Shigeru, K., Kurita, M., Ohta, Y., Tanaka, K., Matsuda, H. \& Kawamukai, M. (1999). Purification, characterization, and gene analysis of a chitosanase (ChoA) from Matsuebacter chitosanotabidus 3001. J Bacteriol 181, 6642-6649.

Parro, V. \& Mellado, R. P. (1993). Heterologous recognition in vivo of promoter sequences from the Streptomyces coelicolor dagA gene. FEMS Microbiol Lett 106, 347-356.

Parro, V. \& Mellado, R. P. (1994). Effect of glucose on agarase overproduction by Streptomyces. Gene 145, 49-55.

Parro, V., San Román, M., Galindo, I., Purnelle, B., Bolotin, A., Sorokin, A. \& Mellado, R. P. (1997a). A 23911 bp region of the Bacillus subtilis genome comprising genes located upstream and downstream of the lev operon. Microbiology 143, 1321-1326.
Parro, V., Vives, C., Godia, F. \& Mellado, R. P. (1997b). Overproduction and purification of an agarase of bacterial origin. $J$ Biotechnol 58, 59-66.

Parro, V., Mellado, R. P. \& Harwood, C. R. (1998). Effect of phosphate limitation on agarase production by Streptomyces lividans TK21. FEMS Microbiol Lett 158, 107-113.

Pelletier, A. \& Sygush, J. (1990). Purification and characterization of three chitosanase activities from Bacillus megaterium P1. Appl Environ Microbiol 56, 844-848.

Price, J. S. \& Storck, S. (1975). Production, purification and characterization of an extracellular chitosanase from Streptomyces. J Bacteriol 124, 1574-1585.

Saito, J. I., Kita, A., Higuchi, Y., Nagat, Y., Ando, A. \& Miki, K. (1999). Crystal stucture of chitosanase from Bacillus circulans $\mathrm{MH}-\mathrm{K} 1$ at $1 \cdot 6-\AA$ resolution and its substrate recognition mechanism. J Biol Chem 43, 30818-30825.

Sambrook, J., Fritsch, E. F. \& Maniatis, T. (1989). Molecular Cloning: a Laboratory Manual, 2nd edn. Cold Spring Harbor, NY : Cold Spring Harbor Laboratory.

Sandorf, P. A. (1989). Chitosan: commercial uses and potential applications. In Chitin and Chitosan, pp. 51-69. Edited by G. Skjak-Braek, T. Anthonsen \& P. A. Sandorf. London: Elsevier.

Shimosaka, M., Kumehara, M., Zhang, X. Y., Nogawa, M. \& Okazaki, M. (1996). Cloning and characterization of a chitosanase gene from the plant pathogenic fungus Fusarium solani. J Ferment Bioeng 82, 426-431.

Somashekar, D. \& Joseph, R. (1996). Chitosanases - properties and applications: a review. Bioresour Technol 55, 35-45.

Swofford, D. L. (1988). Phylogenetic Analysis Using Parsimony (PAUP), version 4.0. Sinauer Associates, Sunderland, MA, USA.

Thompson, J. D., Higgins, D. G. \& Gibson, T. J. (1994). CLUSTAL W : improving the sensitivity of progressive multiple sequence alignment though sequence weighting, position-specific gap penalties and weight matrix choice. Nucleic Acids Res 22, 4673-4680.

Timmons, T. M. \& Dunbar, B. S. (1990). Protein blotting and immunodetection. Methods Enzymol 182, 679-688.

Yabuki, M., Uchiyama, A., Suzuki, K., Ando, A. \& Fujii, T. (1988). Purification and properties of chitosanase from Bacillus circulans MH-K1. J Gen Appl Microbiol 34, 255-270.

Yamada, T., Hiramatsu, S., Songsri, P. \& Fujie, M. (1997). Alternative expression of a chitosanase gene produces two different proteins in cells infected with Chlorella virus CVK2. Virology 230, 361-368.

Received 14 April 2000; revised 20 July 2000; accepted 26 July 2000. 